\title{
Intracellular Alginate-oligosaccharide Degrading Enzyme Activity that is Incapable of Degrading Intact Sodium Alginate from a Marine Bacterium Alteromonas sp.
}

\author{
Tomoo Sawabe, Chihiro Sawada, Eri Suzuki, \\ Yoshio Ezura \\ Laboratory of Microbiology, Faculty of Fisheries, Hokkaido University, Hakodate 041-0821, Japan
}

(Received August 18, 1997)

\begin{abstract}
Intracellular homo- and hetero-polymeric blocks degrading enzyme activity incapable of degrading intact sodium alginate was detected in Alteromonas sp. strain H-4. The enzyme activity for polyM and MG blocks was highest during the late log phase of the bacterium and was not induced by the addition of sodium alginate to the culture medium. The activity for MG random block was as high as that for polyM, but that for polyG block was half and that for sodium alginate was one fifth. At least 4 kinds of enzyme activities, a polyM specific, a MG-polyM specific, and two kinds of polyG specific enzymes, were detected from the crude intracellular fraction, but a trace spot for sodium alginate. Analysis of reaction products using a partially purified preparation of the enzyme indicated that the enzyme generated a saturated diuronate and an unsaturated polyuronide from polyM block. These results suggest that the intracellular enzymes can degrade only oligosaccharides generated from high molecular alginate by the extracellular alginate lyase and may have an important role in the alginate metabolism of the bacterium.
\end{abstract}

Key words: Alteromonas, marine bacterium, intracellular alginate-oligosaccharide degrading enzymes, saturated diuronate

\begin{abstract}
Alginate lyases have been isolated from a wide variety of sources, including marine molluscs, bacteria, fungi and marine brown algae. All alginate lyases described to date are capable of degrading intact high molecular alginate. The substrate specificities of these lyases have been examined by determining whether the enzymes show a preference for (1-4)-linked $\beta$-D-mannuronate (M) or $\alpha$-Lguluronate $(\mathrm{G})$ of the alginate polymer. ${ }^{1,2)}$ There have been no reports of an enzyme showing a preference only for oligosaccharides.

We previously reported on the substrate specificity of the extracellular alginate lyase from a marine bacterium, Alteromonas sp. strain H-4. ${ }^{3)}$ Analysis of the substrate specificity of enzyme for polyM, polyG, MG random blocks and intact sodium alginate indicated that the extracellular alginate lyase is capable of effectively degrading both polyM and polyG blocks, and generates unsaturated tri- through octa-uronate from all of homo- and heteropolymeric substrates. ${ }^{3)}$ Although the marine bacterium can utilize alginate as its sole carbon source, the extracellular alginate lyase did not generate monouronate units. Therefore we thought that further degradation of these unsaturated oligouronates may be needed for the effective utilization of alginate by the bacterium. We have tried to screen intracellular alginate degrading activities of the bacterium using intact sodium alginate as a substrate, however, no activities have been detected. Surprisingly, when homo- and hetero-polymeric blocks derived from sodium alginate were used to screen the activity, a strong activity was observed for the homo- and hetero-polymeric blocks in the intracellular fraction. We report here on the preliminary characterization, including the mode of action, of the in-
\end{abstract}

tracellular homo- and hetero-polymeric block degrading enzyme activity of Alteromonas sp. strain H-4, and on our finding that the intracellular enzymes scarcely degrade intact alginate and generate a dimeric form from polyM. We expect that the intracellular enzymes may play an important role in the degradation and metabolism of oligouronates generated by the extracellular enzyme action of the bacterium.

\section{Materials and Methods}

\section{Bacterial Strain and Culture Medium}

The alginolytic marine bacterium, Alteromonas sp. strain $\mathrm{H}-4$ used in this study has been previously described. ${ }^{3-5)}$ The bacterium was maintained using AI 2 agar medium $^{3)}$ at $20^{\circ} \mathrm{C}$.

\section{Preparation of Intracellular Enzyme}

Alteromonas sp. strain H-4 was cultured in $450 \mathrm{~m} l$ of a seawater broth (pH 7.5) containing $0.5 \%$ casitone (Difco), $0.1 \%$ sodium alginate (Wako Pure Chemical Industries, Ltd; $300-400 \mathrm{cp}$ ) and $75 \%$ seawater at $25^{\circ} \mathrm{C}$. The culture was centrifuged at $10,000 \times g$ for $15 \mathrm{~min}$, and the bacterial cells were collected. To prepare the intracellular enzyme, the cells were washed 3 times with artificial seawater $(\mathrm{NaCl}$ $30.0 \mathrm{~g}, \mathrm{MgCl}_{2} 10.8 \mathrm{~g}, \mathrm{KCl} 0.7 \mathrm{~g}, \mathrm{MgSO}_{4} 5.3 \mathrm{~g}, \mathrm{CaSO}_{4} 1.3 \mathrm{~g}$ in $1,000 \mathrm{~m} l$ distilled water) containing $4 \mathrm{mM}$ Tris ( $\mathrm{pH} 7.8)$. The cells were resuspended in 5 volumes of $0.1 \mathrm{M} \mathrm{Tris-HCl}$ buffer (pH 7.5) per wet weight of the cells and frozen at $-20^{\circ} \mathrm{C}$ overnight. The cell suspension was disrupted by sonication ( $150 \mathrm{~W}, 30 \mathrm{sec}, 5$ times) after thawing. Cell debris was removed by centrifugation $(7,000 \times g, 15 \mathrm{~min}$, 
$4^{\circ} \mathrm{C}$ ). The supernatant was used for crude intracellular enzyme preparation.

To characterize the enzyme activity, the enzyme was partially purified by two-step (50 and $90 \%$ saturated) ammonium-sulfate precipitation. The resultant precipitation was dissolved in $0.1 \mathrm{M}$ Tris- $\mathrm{HCl}$ buffer ( $\mathrm{pH} \mathrm{7.5)}$ and dialyzed in $0.1 \mathrm{M}$ Tris- $\mathrm{HCl}$ buffer $(\mathrm{pH} 7.5)$. The partially purified enzyme was stored at $-20^{\circ} \mathrm{C}$ before use.

\section{Substrate and Enzyme Assay}

PolyM, polyG and $\mathrm{MG}$ random blocks were prepared from sodium alginate according to Haug et al. ${ }^{6}$ ) The uronate composition was quantified using $\mathrm{H}^{1} \mathrm{NMR}^{7,8)}$ and presented in a previous report. ${ }^{3)}$ Mannuronate lactone was purchased from Sigma. The unsaturated oligouronates generated from sodium alginate by Alteromonas extracellular alginate lyase were separated by GCL $25 \mathrm{~m}$ (Saikagaku Kogyo, Co.) gel filtration chromatography using distilled water as an eluent. The active fractions were then pooled and lyophilized.

The thus-prepared intracellular enzyme solution was added to a $0.1 \%$ substrate solution in $0.1 \mathrm{M}$ Tris- $\mathrm{HCl}$ buffer ( $\mathrm{pH} \mathrm{7.5).} \mathrm{The} \mathrm{enzyme} \mathrm{activity} \mathrm{was} \mathrm{monitored} \mathrm{by}$ measuring the increase in absorbance at $235 \mathrm{~nm}$ using a Hitachi spectrophotometer (Type 124) from substrates containing $0.1 \%$ sodium alginate, homo- and hetero-polymeric blocks, mannuronate lactone or the lyophilized unsaturated oligouronate. One enzyme unit was defined as an increase in optical density $(235 \mathrm{~nm})$ of 0.010 per min., ${ }^{4,5)} \mathrm{Al}$ ternatively, enzyme activity was also measured by Somogy-Nelson's reducing sugar determination ${ }^{9)}$ using sodium alginate or homo- and hetero-polymeric blocks as the substrate.

\section{Enzyme Activity on Gels}

The intracellular fractions were prepared at each growth phase (early log phase: $48 \mathrm{~h}$ incubation, late log phase: 72 $\mathrm{h}$, stationary phase: $96 \mathrm{~h}$, and decreasing phase: $120 \mathrm{~h}$ ) of the bacterium. Degrading activities of crude preparation of the intracellular fraction for $\mathrm{Alg}-\mathrm{Na}$ and homo- and hetero-polymeric blocks were investigated using the activity staining technique according to our previous report. ${ }^{3)}$

\section{Characterization of the Enzyme Activity}

The effect of $\mathrm{pH}$ on the partially purified enzyme activity for polyM block was determined by measuring the increase in absorbance at $235 \mathrm{~nm}$ in a broad $\mathrm{pH}$ range buffer $^{10)}$ containing $0.1 \mathrm{M}$ Tris, $0.1 \mathrm{M}$ acetic acid, $0.1 \mathrm{M}$ MOPS, $0.1 \mathrm{M} \mathrm{MES}$ and $0.1 \mathrm{M}$ glycine at adjusted $\mathrm{pH}$ levels of 4 to 10 at $35^{\circ} \mathrm{C}$. The effect of temperature on the activity was measured at temperatures ranging from 10 to $50^{\circ} \mathrm{C}$ in a $0.1 \mathrm{M}$ Tris- $\mathrm{HCl}$ buffer adjusted to $\mathrm{pH} 7.5$.

\footnotetext{
Analysis of Products from Depolymerization of PolyM Block by the Intracellular PolyM Specific Lyase

Substrate solutions containing $6.5 \mathrm{mg} / \mathrm{ml}$ polyM block in $0.1 \mathrm{M}$ Tris- $\mathrm{HCl}$ buffer $(\mathrm{pH} \mathrm{7.5)}$ were incubated for $24 \mathrm{~h}$ at $35^{\circ} \mathrm{C}$ with the partially purified intracellular enzyme. No further increase in absorbance at $235 \mathrm{~nm}$ was detected after this period. The reacted mixture separated and the reaction products were detected and analyzed by the same manner of the previous report. ${ }^{3)}$
}

\section{Results}

Production of Intracellular Homo- and Hetero-polymeric Degrading Enzyme Activity from Alteromonas sp. Strain $H-4$

The intracellular enzyme production profiles of Alteromonas sp. H-4 are shown in Fig. 1. The activities of intracellular enzyme preparation for polyM block and MG random block were higher than those for polyG block and $\mathrm{Alg}-\mathrm{Na}$. The activities for polyG block and $\mathrm{Alg}-\mathrm{Na}$ were half and one fifth of that for MG random block, respectively. The enzyme activities for polyM block and MG random block were highest when the maximum growth of the strain occurred (at $96 \mathrm{~h}$ cultivation).

The intracellular enzyme activity was also detected in the bacterial cells incubated in the seawater broth without sodium alginate (Table 1). The activity for polyM block (980 U/g wet cells) was approximately the same level as the activity from the alginate-deficient medium $(820 \mathrm{U} / \mathrm{g}$ wet cells).

\section{Activity Staining of the Intracellular Fraction on Gel}

Two kinds of degrading spots for polyM, a degrading spot for MG block, and three degrading spots for polyG were detected from the intracellular fraction at each growing stage of the bacterium (Fig. 2). Trace spot was also detected for Alg- $\mathrm{Na}$ (Fig. 2). The $\mathrm{p} I$ value of the degrading spots for polyM blook was 5.4 and 6.7 , respectively. The spot with $\mathrm{p} I 6.7$ corresponded to the MG block degrading spot. A spot with pI 6.7 for polyG blook was only detected at the middle log phase and decreasing phase. Furthermore, other spots with $\mathrm{p} / 7.5$ and 7.1 were detected at the late $\log$ phase to stationary phase, respectively.

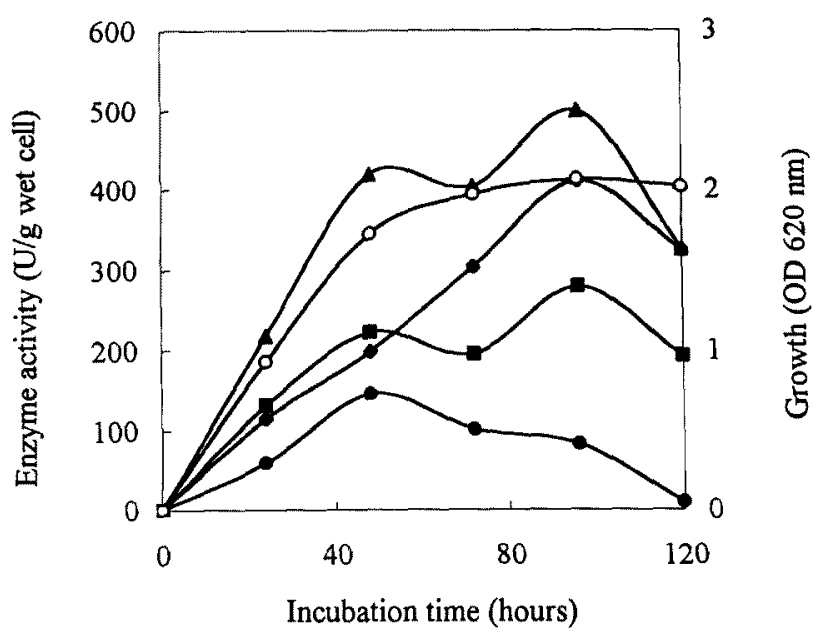

Fig. 1. Alginate degrading enzyme activity and the substrate specificity of intracellular preparation of Alteromonas $\mathrm{sp}$. H-4. Intracellular fraction was prepared at each incubation time of Alteromonas sp. $\mathrm{H}-4$ and its enzyme activity was measured at $30^{\circ} \mathrm{C}$ for sodium alginate ( ), polyM block $(\bullet)$, polyG block ( $\bullet$ ) and MG random block $(\mathbf{\Delta})$ dissolved in $0.1 \mathrm{M}$ Tris- $\mathrm{HCl}$ buffer $(\mathrm{pH} 7.5)$ as substrate. Growth of the strain was simultaneously measured at absorbance of $620 \mathrm{~nm}(\mathrm{O})$. 
Table 1. Effect of sodium alginate addition into the culture medium on the production of the intracellular and extracellular enzyme activities for polyM block of Alteromanas sp. H-4

\begin{tabular}{cc}
\hline Medium & Activity for polyM block \\
\hline Intracellular activity & $(\mathrm{U} / \mathrm{g}$ cells wt) \\
Sodium alginate $(0.1 \%)$ & 980 \\
Without sodium alginate & 820 \\
Extracellular activity & $(\mathrm{U} / \mathrm{m} l)$ \\
Sodium alginate $(0.1 \%)$ & 5.1 \\
Without sodium alginate & $\mathrm{ND}^{*}$ \\
\hline
\end{tabular}

* Not detected

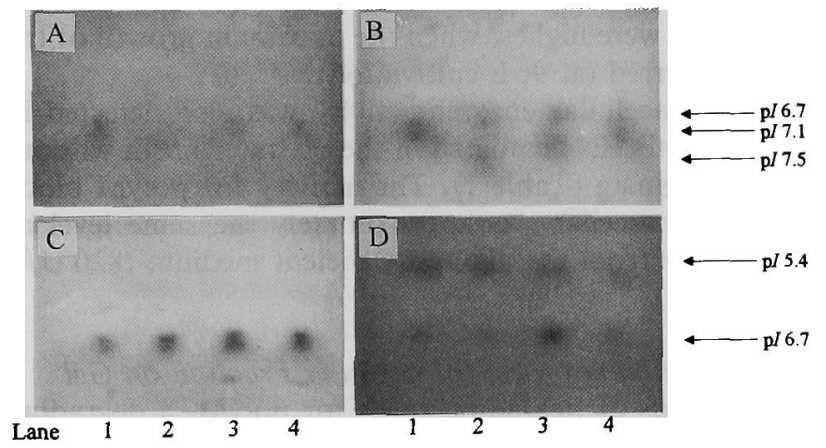

Fig. 2. Activity staining profiles of the intracellular enzymes of Alteromonas sp. H-4 for sodium alginate and homo- and hetero-polymeric blocks after isoelectric focusing gel electrophoresis. (A): sodium alginate, (B): polyG, (C): MG random and (D): polyM blocks. Lane 1: cell-bound activities at $48 \mathrm{~h}$ incubation, lane 2: at $72 \mathrm{~h}$ incubation, lane 3: at $96 \mathrm{~h}$ incubation, lane 4: $120 \mathrm{~h}$ incubation.

Estimation of Cleavage Pattern for PolyM Block by the Intracellular Enzyme Activity

The optimum temperature of the partially purified enzyme activity for polyM blook was $35^{\circ} \mathrm{C}$ and the activity was greatest at $\mathrm{pH} 7.0$ to 7.5. To confirm whether the intracellular enzyme degraded the glycosidic linkage in polyM block or not, the activity was measured by reducing power determination and the UV absorption method under the optimum reaction condition. The results are shown in Fig. 3. The release of reducing sugar from polyM and MG random blocks by the enzyme degradation apparently increased. However, using MG random block as a substrate, no further increase of absorbance and reducing sugar release were observed at the end of the reaction periods, although the absorbance at $235 \mathrm{~nm}$ and the release of reducing sugar from the reaction mixture increased after 10 minutes of incubation. There was no release of reducing sugar from sodium alginate by the enzyme action.

The end products generated from polyM block by the cell-bound enzyme were separated by Cellulofine GCL 25 $\mathrm{m}$ gel filtration chromatography, and the elution profiles of unsaturated oligouronates are shown in Fig. 4. A strong absorption peak at $235 \mathrm{~nm}$, which was not detected in the polyM block (Fig. 4. A-S), was observed around the void volume of the column after the enzyme action (Fig. 4. ADigest). The corresponding peak contained considerable amounts of uronate (Fig. 4. B-Digest). Although a uronate peak was detected in the polyM block used as substrate at the same elution point (Fig. 4. B-S), the uronate content of

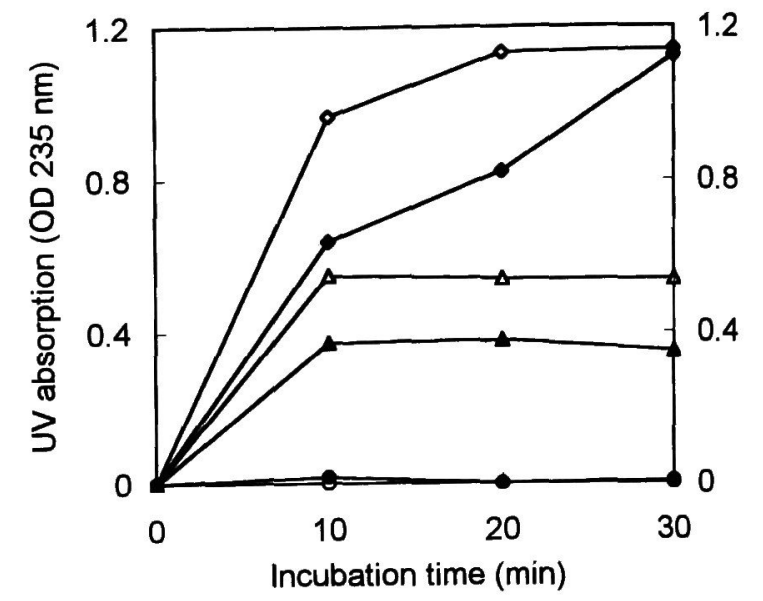

Fig. 3. Measurement of the partially purified intracellular activity for polyM block by UV absorption (open symbol) and reducing power determination (closed symbol). Activity of the partially purified cellbound enzyme was measured at $30^{\circ} \mathrm{C}$ for sodium alginate $(O$ and $\bullet$ ), polyM block ( $\diamond$ and $\bullet$ ) and MG random block ( $\Delta$ and $\Delta$ ) dissolved in $0.1 \mathrm{M}$ Tris- $\mathrm{HCl}$ buffer $(\mathrm{pH} 7.5)$ as a substrate.

the peak decreased by half (Table 2 ). The unsaturated polysaccharides contained within the peak were estimated to have DP 23 (Table 2). This value is higher than the molecular weight $(4,000)$, which is the exclusion limit of Cellulofine GCL $25 \mathrm{~m}$ as sugar. Four minor UV-absorption peaks were also detected (Fig. 4. A-Digest), but the uronate contents of the corresponding peaks were low (Fig. 4. B-Digest). Another uronate peak (peak I in Fig. 4.B-Digest) was observed after the UV-absorption peak (Fig. 4.A-Digest). This uronate peak did not show UV absorption and contained a high amount of reducing residues (Table 2). The DP of the saturated uronate was estimated to be 2 , and $1.8 \mathrm{mg}$ of uronates was converted to the dimeric form from $6.5 \mathrm{mg}$ (equivalent to uronate) of polyM block by the enzyme action (Table 2 ). These results show that $4.7 \mu \mathrm{M}$ saturated dimeric form and $0.7 \mu \mathrm{M}$ unsaturated polyuronate (DP 23) are generated from polyM block.

\section{Discussion}

In addition to the production of an extracellular, nonspecific alginate lyase, ${ }^{3)}$ the marine bacterium Alteromonas sp. H-4 produces intracellular degrading activity only for homo- and hetero-polymeric blocks derived from alginate. After measuring the intracellular enzyme activity using the two methods, it was apparent that the intracellular enzyme activity is limited for intact alginate (Figs. 1, 2 and 3). The enzyme activity was strong for MG and polyM, but the enzyme activity for MG quickly reached a plateau (Fig. 3). Using polyM block, the partial characterization of the intracellular enzymes, which contained 4 kinds of enzymes, generates a saturated diuronate and unsaturated polyuronate with a longer glycosidic chains (Fig. 4 and Table $2)$. The molar ratio of saturated diuronate and unsaturated polyuronates was estimated to be $4.7 \mu \mathrm{M}(\mathrm{DP}=2)$ and $0.70 \mu \mathrm{M}(\mathrm{DP}=23)$. It appears that the intracellular enzymes may have hydrolytic cleavage action. However, the intracellular enzyme preparation contained at least 4 kinds 

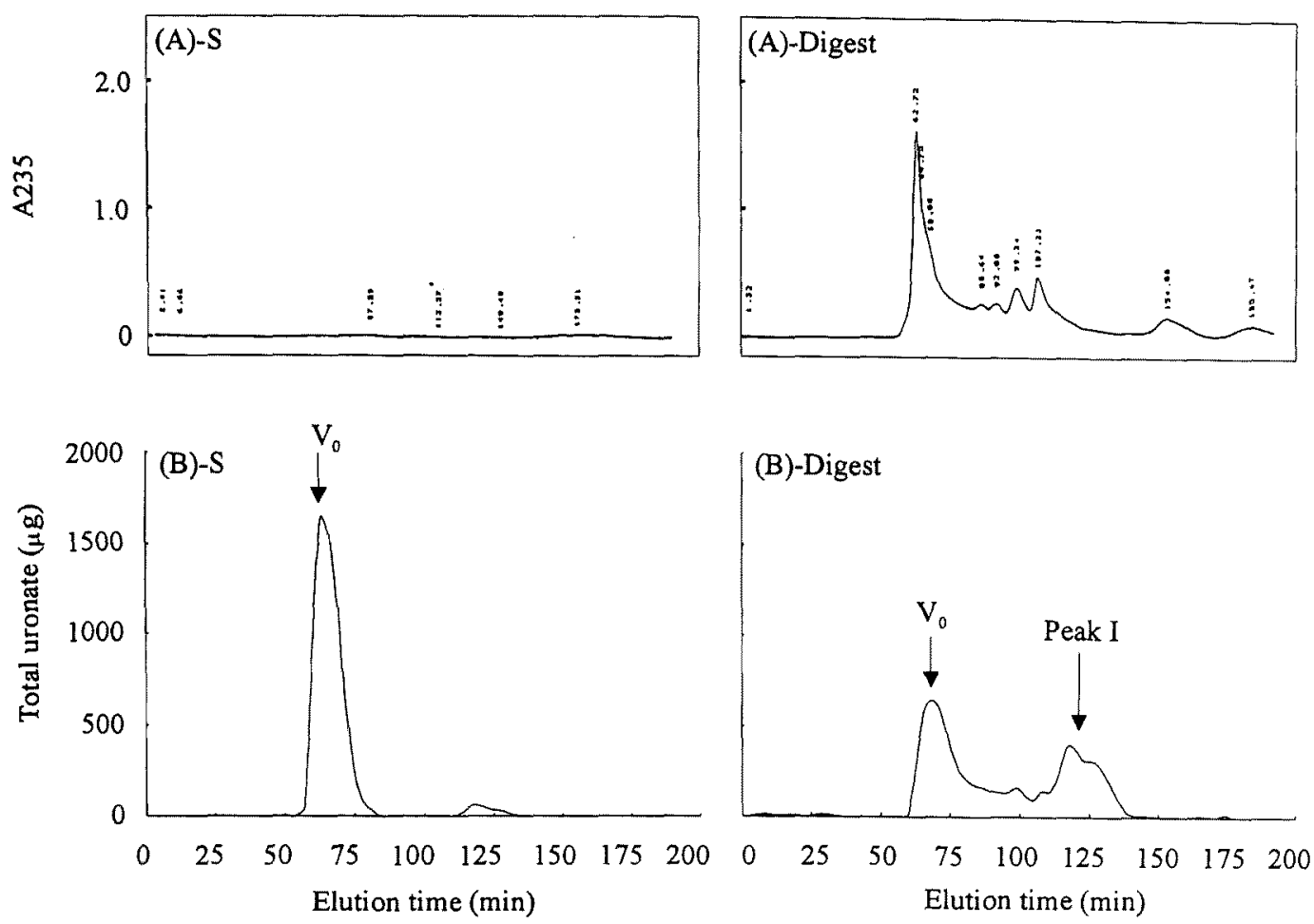

Fig. 4. Elution profiles of the reaction products from polyM block generated by the intracellular polyM specific lyase degradation. Substrate solutions containing $6.5 \mathrm{mg} / \mathrm{m} l$ polyM block in $0.1 \mathrm{M}$ Tris- $\mathrm{HCl}$ buffer $(\mathrm{pH} 7.5)$ were incubated for $24 \mathrm{~h}$ at $35^{\circ} \mathrm{C}$ with the partial purified polyM specific lyase of Alteromonas sp. H-4. The undigested polyM block and teaction mixture was applied to a column $(1.34 \mathrm{~cm} \times 40 \mathrm{~cm})$ of Cellulofine GLC $25 \mathrm{~m}$ and eluted with $0.1 \mathrm{M} \mathrm{Na}_{2} \mathrm{SO}_{4}$ at $28 \mathrm{ml} / \mathrm{h}$. The undigested polyM block ((A)-S) and reaction products ((A)-Digest) were detected at 235 $\mathrm{nm}$ using a Hitachi L-4200 UV-VIS detector. The total amounts of uronate of the peaks were determined after separation of undigested polyM block ((B)-S) and reaction products ((B)-Digest) by gel-filtration chromatography. $\mathrm{V}_{0}$ indicates void volume of the column.

Table 2. Analysis of reaction products from polyM block generated by the enzymes

\begin{tabular}{|c|c|c|c|}
\hline \multirow[t]{2}{*}{ Peak } & \multicolumn{2}{|c|}{$\begin{array}{l}\text { Total amounts in a } \\
\text { corresponding peak (mg) }\end{array}$} & \multirow{2}{*}{$\begin{array}{l}\text { Estimated DP } \\
\text { of reaction product }{ }^{*_{2}}\end{array}$} \\
\hline & Uronate $^{* 1}$ & Reducing termini & \\
\hline Peak $V_{0}$ & $3.2(0.7 \mu \mathrm{M})$ & 0.12 & 22.9 \\
\hline Peak I & $1.8(4.7 \mu \mathrm{M})$ & 0.66 & 2.2 \\
\hline
\end{tabular}

of enzymes with different substrate specificity and $\mathrm{p} I$. It is not clear whether the generation of the saturated diuronate may be attributable to one of the enzymes in the intracellular preparation or to the combined action of all enzymes.

There have been no reports of intracellular enzymes that are incapable of degrading intact sodium alginate among all described alginate lyases. ${ }^{1,2}$ Despite the fact that the intracellular enzyme of Alteromonas was incapable of degrading sodium alginate, the absorbance of the unsaturated oligouronate solution prepared from alginate digests by the Alteromonas extracellular alginate lyase doubled after the intracellular enzyme activity (data not shown). These observations in this study suggested that the intracel- lular enzymes may be specific for oligosaccharides. Many aspects of the mode of enzyme action remain unresolved. In future studies, we plan to homogeneously purify the enzymes and examine then in detail.

Among intracellular alginate lyases reported in Klebsiella aerogenes (type 25$),{ }^{11}$ Pseudomonas spp. ${ }^{12-14)}$ Sphingomonas sp., ${ }^{15)}$ some marine pseudomonad, ${ }^{16,17)}$ Beneckea pelagia ${ }^{149}$ Azotobacter spp. ${ }^{187}$ and Alteromonas sp. ${ }^{19)}$ a few intracellular enzymes were suggested to play a role in the final digestion process of alginate metabolism by bacteria. As Romeo et al. ${ }^{19)}$ proposed in marine Alteromonas $\mathrm{sp}$, a high molecular alginate would be degraded to oligosaccharides by an extracellular, endo-acting enzyme of the bacterium, and the oligosaccharides would then be degraded to monomers by an intracellular exo-acting enzyme, and metabolized. Alteromonas sp. strain H-4 is capable of utilizing alginate as its sole carbon source. ${ }^{4)}$ High molecular alginates can be degraded by the extracellular enzyme to shorter-chained oligouronates, and the oligouronates may then be degraded to the shorter, dimeric form, by the intracellular enzymes. Regarding alginate metabolism by Alteromonas, the production of extracellular alginate lyase with broad substrate specificity and intracellular enzyme with oligouronate specificity are reasonable, although details of the metabolic pathway of alginate remain unsolved. The intracellular enzyme activity was also constitutively expressed in the bacterium similar to the extracellular alginate lyase. ${ }^{4)}$ The relationship between 
the extracellular alginate lyase showing non-limited substrate specificity and the intracellular polyM block specific lyase in the alginate metabolism of Alteromonas sp. strain H-4 must be characterized.

Acknowledgments We thank Professor P. Gacesa, University of Central Lancashire, and Professor B. Larsen, University of Trondheim, for their critical readings of the manuscript.

\section{References}

1) P. Gacesa: Enzymic degradation of alginates. Int. J. Biochem., 24, 545-552 (1992).

2) I. W. Sutherland: Polysaccharide lyases. FEMS Microbiol. Rev., 16, 323-347 (1995).

3) T. Sawabe, M. Ohtsuka and Y. Ezura: Novel alginate lyase from a marine bacterium Alteromonas sp. Carbohyd. Res., 304, 69-76 (1997).

4) T. Sawabe, Y. Ezura and T. Kimura: Characterization of an alginolytic marine bacterium from decaying Rishiri-kombu Laminaria japonica var. ochotensis. Nippon Suisan Gakkaishi, 58, 141-145 (1992).

5) T. Sawabe, Y. Ezura and T. Kimura: Purification and characterization of an alginate lyase from marine Alteromonas sp. Nippon Suisan Gakkaishi, 58, 521-527 (1992).

6) A. Haug, B. Larsen and O. Smidsrød: Studies on the sequence of uronic acid residues in alginic acid, Acta Chem. Scand., 21, 691704 (1967).

7) H. Grasdalen, B. Larsen and O. Smidsrad: A P.M.R. study of the composition and sequence of uronate residues in alginates. Carbohyd. Res., 68, 23-31 (1979).

8) A. Penman and G. R. Sanderson: A method for the determination of uronic acid sequence in alginates. Carbohyd. Res., 25, 273-282 (1972).

9) M. Somogyi: Note on sugar determination. J. Biol. Chem., 195, 19-23 (1952).

10) H. Sawada, H. Yokosawa and S. Ishii: Trypsin-like enzyme from eggs of the ascidian (protochordate). J. Biol. Chem., 259, 29002904 (1984).

11) B. Lange, J. Wingender and U. K. Winkler: Isolation and characterization of an alginate lyase from Klebsiella aerogenes. Arch. Microbiol., 152, 302-308 (1989).

12) S. Kinoshita, Y. Kumoi, A. Ohshima, T. Yoshida and N. Kasai: Isolation of an alginate-degrading organisms and purification of its alginate lyase. J. Ferment. Bioeng., 72, 74-78 (1991).

13) A. Linker and L. R. Evans: Isolation and characterization of an alginase from mucoid strains of Pseudomonas aeruginosa. $J$. Bacteriol., 159, 958-964 (1984).

14) I. W. Sutherland and G. A. Keen: Alginases from Benekea pelagia and Pseudomonas spp. J. Appl. Biochem., 3, 48-57 (1981).

15) Y. Yonemoto, K. Murata, A. Kimura, H. Yamaguchi and $\mathrm{K}$. Okayama: Bacterial alginate lyase: characterization of alginate lyase-producing bacteria and purification of the enzyme. $J$. Ferment. Bioeng., 72, 152-157 (1991).

16) I. W. Davidson, I. W. Sutherland and C. J. Lawson: Purification and properties of an alginate lyase from a marine bacterium. Biochem. J, 159, 707-713 (1976).

17) J. Preiss and G. Ashwell: Alginic acid metabolism in bacteria-I. J. Biol. Chem., 237, 309-316 (1962).

18) L. Kenedy, K. McDowell, and I. W. Sutherland: Alginases from Azotobacter species. J. Gen. Microbial., 38, 2465-2471 (1992).

19) T. Romeo, J. C. Bromley and J. F. Preston III: Alginate lyase of varying substrate specificities from marine bacteria, in "Biomass energy development"' (ed. by W. H. Smith), Plenum Press, New York. 1986, pp 303-320. 